\title{
Systems biology of vintage and terroir: adding some flavor to the wine grape transcriptome
}

\author{
Hildegarde Heymann* and Dario Cantu
}

\begin{abstract}
High-throughput genomic tools provide an unprecedented opportunity to study the impact of environmental variables on complex phenotypes at the genome scale. We welcome the establishment of an experimental framework that uses omics approaches to determine the effect of the climate and viticultural practices on the grape berry physiology. However, in this commentary, we argue that genomics and genetics studies of wine grapes need to be integrated with descriptive sensory analysis of their resulting wines.
\end{abstract}

\section{Commentary}

Del Santo et al. [1] have published a study in Genome Biology, which provides a first serious attempt to establish a rigorous and quantitative experimental approach to answer important questions on the relationship between environmental factors, agronomical practices, and grape berry metabolism. The same approaches can and should be applied to multiple varieties with one of the pertinent questions being 'Are the plastic and constitutive genes conserved across varieties?' Additionally it is important to keep in mind that wine is a very complex matrix and it is entirely possible that relatively large effect in the berries translate to negligibly small effects in the resultant wine and in some cases, even if larger effects are found, consumers (the ultimate reason for producing the wine) may not notice these effects. Therefore it would be fascinating to start looking at well establish concepts of wine making, such as the vintage effect, in terms of genes and metabolites. Will we be able to predict a good, an excellent, or a bad year by measuring the activities of specific genes during berry development? A deeper understanding of the grapevine transcriptional and metabolic plasticityin relation to environmental, geographical or agronomical variables will require not only more data (more genotypes, more environments, more years), experimental designs controlling for specific effects and co-variables, and genetic perturbations, but also that we extend and integrate genomics level

\footnotetext{
* Correspondence: hheymann@ucdavis.edu

Department of Viticulture and Enology, University of California Davis, Davis, CA 95616, USA
}

data with quantitative sensory profiles of the wines produced from the very same berries used for the genomics studies.

Many of the flavors associated with wine are grapederived, such as 2-methoxy-3-isobutyl pyrazine which adds a green pepper flavor to especially Cabernet sauvignon and Sauvignon blanc wines [2], while others are glycosidically bound in the grape berry but are released during the fermentation process, for example 3mercaptohexyl-acetate which adds a passion fruit-like odorto Sauvignon blanc wines [3]. Other flavor compounds such as esters are produced by the yeast during fermentation [4] and some are produced by the malolactic bacteria after fermentation (an example would be the buttery flavor of diacetyl [4]). Additionally, aging in oak barrels adds yet more flavor compounds such as vanillin and eugenol [5]. The resultant complex flavor matrix can be evaluated quantitatively through sensory descriptive analysis (DA). In DA a group of about 12 panelists are trained to describe differences among wines using consensus derived attributes that are anchored by specific reference standards [6]. The wines are evaluated by each panelist in triplicate and the data are analyzed using multivariate techniques that are very similar to those used by systems biologists [7]. The quantitative nature of sensory DA data would make it relatively simple to integrate the sensory data with transcriptomic and metabolomic data [8]. Santos et al. (2013, [1]) found that the warmer year (2007) resulted in very specific gene regulation changes that were also relatable to the metabolomic profiles of the 2007 grape berries. Sadras et al. (2013 [9]) in a replicated artificially heated vineyard 
study found that elevated grapevine temperatures led to changes in phenolic content. Similarly, Heymann et al. (2013 [10]) found that a warmer year (interestingly also 2007 but in California) led to very different sensory profiles for the resultant wines than wines made in 2006 and 2008.

It would be fascinating to extend the grape berry phenotype to the "real" wine grape phenotype, the wine. Ideally, one would need to do a fully replicated vineyard experiment to determine the variability in the transcriptome and the grape berry metabolomics within a vineyard and across vineyards with differing climate and viticultural practices. The berries should be harvested at the same maturity levels and then fermented into wine using highly controlled replicate fermentations at moderate scale to determine fermentation variability. The resultant wines should then be chemically analyzed for volatile and non-volatile compounds as well as sensorially using a well trained descriptive analysis panel. If any large changes are found due to vineyard effects then a consumer panel should evaluate the wines hedonically.

The work by Del Santo et al. provides an effective experimental frameworkthat should be extended in future works to the chemical and sensory evaluations of wines. Wine grapes used for the genomics analysis can be fermented into wine under controlled conditions and the chemical and sensory changes in the wines can be then integrated with transcriptomic and metabolomicprofilesto determine the impact of environmental and agronomical factors on the ultimate wine grape phenotypes, the wines.

Abbreviations

DA: Descriptive analysis.

\section{Competing interests}

The authors declare that they have no competing interests.

Received: 31 May 2013 Accepted: 14 June 2013

Published: 25 June 2013

\section{References}

1. Del Santo S, Battista Tornielli G, Zenoni S, Fasoli M, Farina L, Anesi A, Guzzo F, Delledonne M, Pezzotti M: The plasticity of the grapevineberrytranscriptome. Genome Biol 2013, 14:R54

2. Chapman DM, Thorngate JH, Matthews MA, Guinard J-X, Ebeler SE: Yield effects on 2-methoxy-3- isobutylpyrazine concentration in Cabernet Sauvignon using a solidphase micro extraction gas chromatography/ mass spectrometry method. Journal of Agricultural and Food Chemistry 2004, 52:5431-5435.

3. Harsch MJ, Gardner RC: Yeast genes involved in sulfur and nitrogen metabolism affect the production of volatile thiols from Sauvignon blanc musts. Appl Microbiol Biotechnol 2013, 97:223-235.

4. Polášková P, Herszage J, Ebeler SE: Wine flavor: chemistry in a glass. Chem Soc Rev 2008, 37:2478-2489.

5. Prida A, Chatonnet P: Impact of oak-derived compounds onthe olfactory perception of barrel-aged wines. Am J Enol Vitic 2010, 61:408-413.

6. Lawless HT, Heymann H: Chapter 12: Descriptive Analysis. In Sensory Evaluation of Foods: Principles and Practices. New York, New York: Springer; 2010.

7. Lawless HT, Heymann H: Chapter 18. Data Relationships and Multivariate Analysis. In Sensory Evaluation of Foods: Principles and Practices. New York, New York: Springer; 2010.
8. Robinson A, Adams DO, Boss PK, Heymann H, Solomon PS, Trengove RD: The relationship between sensory attributes and wine composition for Australian Cabernet Sauvignon wines. Australian Journal of Grape and Wine Research 2011, 17:327-340.

9. Sadras VO, Moran MA, Bonada M: Effects of elevated temperature in grapevine. I. Berry sensory traits. Australian Journal of Grape and Wine Research 2013, 19:95-106.

10. Heymann H, LiCalzi M, Conversano MR, Bauer A, Skogerson K, Matthews M: effects of extended grape ripening with or without must and wine alcohol manipulations on Cabernet Sauvignon wine sensory characteristics. South African Journal of Enology and Viticulture 2013, 34:86-99.

\section{doi:10.1186/2044-7248-2-20}

Cite this article as: Heymann and Cantu: Systems biology of vintage and terroir: adding some flavor to the wine grape transcriptome. Flavour 2013 2:20.

\section{Submit your next manuscript to BioMed Central and take full advantage of:}

- Convenient online submission

- Thorough peer review

- No space constraints or color figure charges

- Immediate publication on acceptance

- Inclusion in PubMed, CAS, Scopus and Google Scholar

- Research which is freely available for redistribution 